\title{
COMPETENCIES PROFILES OF SUCCESSORS IN CONTEMPORARY FAMILY FIRMS
}

\author{
Mariola Dźwigot-Barosz \\ Silesian University of Technology, Gliwice, Poland \\ e-mail: mariola.dzwigol-barosz@polsl.pl
}

\begin{abstract}
The article presented issues related to the competencies of successors in contemporary family firms. A particular emphasis was placed on the significance of leadership competencies in the management of the contemporary company.

The author underlined the role of emotional intelligence which is an indelible part of the successors' competencies as well as competencies related to the upbringing and socialisation.

The paper also presented a profile of competencies of successors, which profile related to those competencies that determine the effective management of the family businesses. It was elaborated on the basis of research results quoted in other researchers' works, as well as findings of the author's own research.

Purpose: to draw the readers' attention to the significance of competencies of successors in contemporary family firms, with a particular emphasis on the leadership competencies, emotional intelligence and competencies related to the upbringing and socialisation.

Methodology: literature research, author's own survey research related to successors competencies Findings: Those family enterprises that anticipate succession process should focus on competence profiles of their successors, while taking into consideration the role played by the competencies related to emotional intelligence. The findings were confirmed by the author's own research, where 19 competencies were selected from 33 competences grouped in 11 emotional intelligence-related competence groups; the said competencies, according to the successors, are of the key importance in the process of succession in family companies.

Originality/value: Upon the analysis of the studies by the researchers cited herein, and of the results of the author's own research related to successors competencies being a determinant for effective management of modern family firms, the author put an emphasis on three groups of competencies, as provided for in the profiles of competencies of successors in modern family companies.
\end{abstract}

Keywords: competences, emotional intelligence, successor, family businesses

Paper type: Research paper

\section{Introduction}

Family firms have been the oldest way of doing business, and as such they constitute one of the pillars of the world-wide economy. Their creation, operation and collapse considerably affect the development of both national and global 
COMPETENCIES PROFILES OF SUCCESSORS

Mariola Dźwigoł-Barosz economies. A long-term perspective of running a business by a future generation, as well as combining family-related and managerial functions result in distinct identities of the said entities (Sułkowski and Marjański, 2009).

The fact that numerous Polish companies are now facing key decisions related to the transfer of power, knowledge and property is getting more and more obvious. The first wave of succession is coming. Therefore, the company founders - the ones who took risks, sacrificed their work, energy and money to establish their business are about to hand their companies over to their successors. The first intergenerational change is connected with the necessity to define by a senior member and the family, a new vision of the company, as well as to establish new systems of values and formal regulations as to the property and power in the family firm.

However, under the highly undetermined conditions, the managers of contemporary companies have to adopt the roles of change leaders, knowledge managers, managers-entrepreneurs, team managing managers, decision-makers willing to take risks, analysts, coaches and masters looking after the development of their own competencies. It is one of the signs proving that the business environment is undergoing significant changes, and that the executives are about to face more and more daunting tasks.

The concept of management in family businesses requires a different approach to functions executed by contemporary managers and their successors. Moreover, it requires to elaborate new models of education, "tailored" to the needs of family businesses, which, in the larger extent, will take into consideration the following aspects: development of leadership skills, development and improvement of employees' competencies, practical motivation skills. In the family businesses, one can combine business and their family by shaping entrepreneurial values during the upbringing of the generation of successors, the latter regarded as future managers (Więcek, 2014).

Owners of family businesses require from their successors to have numerous multi-discipline skills, the acquisition of which is a highly time - and workconsuming process. The acquisition and use of the skills are to ensure that the family-run enterprise will continue to develop in compliance with a determined strategy.

Competencies of successors are subject to studies by numerous members of the scientific community. Elaborating a set of competencies for successors, necessary to run a family business, is a complex and ambiguous process. Family enterprises which, under the long-term strategy, anticipate succession processes, should take into account the successors' competence profiles. Taking into account the complexity of the business environment, it seems to be rightly justified to determine essential competencies, allowing to cope with challenges imposed on successors in the contemporary family businesses. 
The aim of the paper is to draw the readers' attention to the significance of competencies of successors in contemporary family firms, with a particular emphasis on the leadership competencies, emotional intelligence and competencies related to the upbringing and socialisation.

\section{Importance of leadership competencies in the management of modern companies}

Having a strong leadership background is a basic condition for the development of each company. This truth was confirmed by a research on "Leadership competencies" conducted by Deloitte. In the research 172 managers from the largest Polish companies were asked about roles of leaders. Then, in April 2014, the same question was posed on a nation-wide scale to a representative sample of 1,110 Poles. As a result, a new model of leadership competencies could have been established in Poland (Thor and Georgijew, 2014).

A group of business experts, scientists, advisors and HR practitioners selected and defined a Model of Leadership Competencies, necessary to manage a modern company. Ten most important competencies were defined, necessary for effective management in new times; the competencies that would match present and future challenges imposed on companies in the post-crisis era.

A decalogue of a new leader encompasses the following competencies (Thor and Georgijew, 2014):

- Adopting a wider perspective. Interpreting the company's stance in the broad business context, assessing properly its development opportunities, recognising potential threats and limitations; being familiar with market trends and being able to make use of the said phenomena to the benefit of the company.

- Focus on the goodwill increase. A strong pro-success attitude, building a strong market position of the company; setting challenging targets and making efforts to fulfil them; recognising new opportunities to achieve a competitive edge and growth, promoting innovations.

- Developing visions and fulfilling them. Being able to present a development strategy in a clear way, being able to fulfil the strategy with passion.

- Flexibility in the operation of the company. Being able to act effectively and constructively under pressure and in stressful situations. Being able to adjust to changeable external conditions.

- Promoting changes. Recognising and promoting advantages triggered by changes (change leaders); creating a positive, pro-change attitude, recognising risks connected to changes and taking responsibility for the risks. 
COMPETENCIES

PROFILES OF

SUCCESSORS

Mariola Dźwigoł-Barosz
- Financial perspective. Making use of financial analyses while elaborating strategic targets and taking key decisions.

- Building effective relationships. Fostering a net of effective relations within the company and beyond; adhering to ethical rules, declarations, and consequences between declarations and actions.

- Talent development. Creating favourable work conditions, being willing to accept suggestions from the workers, developing the employer's good reputation. Promoting talents and educating a generation of successors, delegating competencies to skilled managers.

- Influencing others. Providing clear and coherent messages and ideas. Informing of the plans as to the company development, accepting a role of a leader and authority; commitment to the elaboration of new ideas and innovative solutions. Energy, passion and involvement.

- Building a value-based company. Building a stability in the long-term perspective. Respect for diversity, business ethics, responsibility and understanding of the CSR [1] rules - these are distinctive features of a leader.

There is no doubt that the managers are responsible for developing behavioural patterns, organisational changes, and learning new ways of how to act. They are also responsible for initiating and propagating knowledge-based solutions in the companies.

Regardless of the economic situation, the executives still value the people management most. Over $65 \%$ of the surveyed managers, within the scope of Talent Club [2], believe that the staff flexibility when facing a problem is the most important feature of a good employee. The respondents claimed that managers, although acting in critical situations, should not act ruthlessly, manipulate, solve problems in an authoritarian way or relentlessly pursue their aims. The manager should be surrounded by people with whom he/she likes working, people who create a positive atmosphere at work and form an effective and powerful team. Those managers who make use of their employees' talents, knowledge and skills in order to pursue one common aim achieve the best results. The manager should become a leader for his/her employees, highlight the aims and allow the staff to choose the best way. The employers are looking for creative and independent workers for whom the workplace is not necessarily a synonym for a rat race, since successes are achieved by those who can act along with the managed team. Thus the managers rejected, as useless and unneeded, the ruthlessness and lack of sensitivity, so much nurtured some years ago by the best executives. However, the managers stated that the most valuable assets are employees' professionalism and expertise - being a well-educated and talented expert in one's area [3].

One of the key types of strong leadership was defined bySmoliński and Zakrzewska (2017). The authors stated that a leader is a highly efficient person; 
the efficiency helps him/her to be a strategist, originator, talent hunter and leader. He/she can boast knowledge, charisma, honesty, emotional intelligence, stress resistance and ability to learn. The position of the leader should be forged out of one's attitude, passion, commitment, courteousness and empathy. Such a combination determines the leadership effectiveness and its quality.

\section{Role of the successors' competencies related to emotional intelligence}

There is not even a single area in life in which emotional intelligence would not play an important role. The emotional intelligence acts as a drive for people to develop their own potential, it allows them to take hold of bad habits, helps to set interpersonal borders and facilitates the development of satisfactory relationships, in both private and professional life.

Emotional intelligence is people's personal competencies, understood as their ability to recognize their own and other people's emotional states, as well as the ability to make use of their own emotions and tackle other people's emotional states (Mikołajewska and Mikołajewski, 2013). It involves one's ability to control and regulate one's mood, which, in turn, is helpful in coping with various situations. The ability to understand emotions and make right use of them plays a key role in the human life.

The studies on emotional intelligence were initiated by Gardner. He distinguished (Gardner, 1989):

- Intrapersonal intelligence involving the capacities of understanding and controlling of one's own emotions (relationship with the self),

- Interpersonal intelligence involving the capacities of understanding and coping with interpersonal relations (relations with the others).

Interpersonal intelligence, also known as social intelligence, means one's capacity to get on well with people and be willing to co-operate with them. It also means the empathy, the capacity to enter into deep relationship with the others, understand their needs, and promote desired attitudes and reactions. Moreover, the social intelligence consists of empathising with other people's emotions and building of trust.

The importance of social intelligence in family enterprises has been confirmed by the findings of the report entitled „Competencies of the future in the family businesses 2017" [4]. The analysis of responses submitted by all companies proves that social intelligence is the most desired competence of the future. Over $3 / 4$ of surveyed businesspeople declare both the willingness and need to develop the said competence.

The studies on the specific character of diagnoses and assessments of the use of successors' competencies confirm that the competencies related to emotional intelligence are essential for succession processes. 
COMPETENCIES PROFILES OF SUCCESSORS

Mariola Dźwigoł-Barosz
A list of successors' competencies, needed in the succession process, elaborated on the grounds of a study carried out by Więcek-Janka and Hadryś-Nowak (WięcekJanka and Hadryś-Nowak, 2016) in 2014, enumerates 20 competencies, out of which eleven competencies refer to emotional intelligence. One can find here: diligence, communication skills, organisational skills, accuracy, resourcefulness, commitment, resistance to stress, firmness, ambition, motivation, courage. It was emphasised that the most frequently chosen competencies are, among others, diligence and commitment, whereas the competence of diligence was granted the highest average mark. Furthermore, Polish successors of family businesses stated that the abilities to introduce changes and adapt to the closest and more remote environment of the enterprise are the most useful skills in the succession process. Adaptive skills, i.e. the ability to change and the ability to act and make decisions are also regarded as competencies related to emotional intelligence.

The classification of successor competencies used in the succession process implies their various origins. Providing the family enterprise with multi-generation resources and development, and ensuring that the enterprise is highly efficient are, to a large extent, dependent on relevant competence potential of successors. Those family enterprises that anticipate succession process should focus on competence profiles of their successors, while taking into consideration the role played by the competencies related to emotional intelligence.

The findings were confirmed by the author's own research [5], where 19 competencies were selected from 33 competences grouped in 11 emotional intelligence-related competence groups (Goleman, 1996); the said competencies, according to the successors, are of the key importance in the process of succession in family companies.

On the basis of calculations, it transpired that the successors shared the same views as to all competencies. With regard to the above, it was concluded that as essential successors' competencies one shall view the competencies which:

- Got 5 points from at least $50 \%$ successors,

- the average amount of points granted to a given competence by successors equalled, at least, 4.5 .

Table 1 below presents competencies that fulfilled the above-mentioned conditions.

Table 1. Key competencies of successors, related to emotional intelligence

Source: Own work.

\begin{tabular}{cl}
\hline No. & SUCCESSORS' KEY COMPETENCIES RELATED TO EMOTIONAL INTELLIGENCE \\
\hline 1 & Self-esteem \\
\hline 2 & Self-efficacy \\
\hline 3 & Awareness of one's own abilities and opportunities \\
\hline 4 & Awareness of one's own limitations \\
\hline 5 & Ability to consciously control one's own emotional states \\
\hline
\end{tabular}




\begin{tabular}{cl}
\hline No. & SUCCESSORS' KEY COMPETENCIES RELATED TO EMOTIONAL INTELLIGENCE \\
\hline 6 & Ability to cope with stress \\
\hline 7 & Ability to say "no" firmly and in a way which does not harm other people \\
\hline 8 & Argumentation skills \\
\hline 9 & Effective communication \\
\hline 10 & Ability to settle conflicts \\
\hline 11 & Ability to create visions and encourage other to fulfil them \\
\hline 12 & Ability to win supporters \\
\hline 13 & Charisma \\
\hline 14 & Ability to work in a group to achieve common aims \\
\hline 15 & Optimism \\
\hline 16 & Willingness to change \\
\hline 17 & Willingness to take decisions and act \\
\hline 18 & Willingness to act and take decisions when under pressure \\
\hline 19 & Willingness to take responsibility for tasks and their execution \\
\hline
\end{tabular}

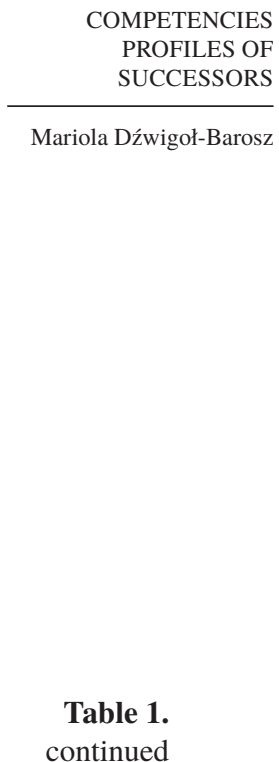

The significance of competencies in the area of emotional intelligence was also underlined by Weroniczak, who defined the following qualities, i.e. (Weroniczak, 2012):

- communication skills,

- empathic perception,

- ability to solve conflicts through co-operation,

- understanding of change processes,

- seeing diversity as a resource,

- regarding the company and the family as intertwined systems,

as psychological and social skills, necessary to create space that promotes an intergenerational dialogue, existing in the succession process.

The managing of the family enterprise is undoubtedly a test of successors' competencies. It is of great importance for managers to have competencies related to emotional intelligence as the managers shape the culture of the entire organisations, set development trends and motivate the staff to work more effectively. Creating the empathy-based atmosphere being, more often than not, a factor that builds team stability, is one of the key competencies of contemporary businesspeople. Those managers who can act wisely and keep their teams together are able to carry on and expand their family businesses. 
COMPETENCIES PROFILES OF SUCCESSORS

Mariola Dźwigoł-Barosz

\section{Profile of successor competencies in contemporary family businesses}

The successors of the contemporary companies have to face numerous challenges, which the senior members of the family firms often regard as a chance to maintain the company, develop it or even restore it.

The most essential traits of character, from the perspective of the entrepreneurial process, include the readiness to take risks, motivation for achievement and inner control, thanks to which a businessman is aware of his/her ability to affect the environment and control actions to be taken. What is more, the traits of character of effective businesspeople include determination and persistence to reach one's aim, passion and ability to inspire other people, diligence and ability to make decisions. Many of the said traits are shaped, not entirely consciously, by parents in the environment of the family business (Gutkova, 2014).

Selecting a successor requires from the senior members of the family companies an ability to assess candidates objectively, not only through the prism of family bonds, but mainly with regard to their competencies.

The study on specific character of diagnosis and assessment of competencies of the successors under the first succession stage in the family businesses in Poland was conducted by Więcek-Janka in 2014. The study, which involved 106 successors and potential successors of family firms, brought about results on the significance of successors' competencies and features. 20 features and competencies were assessed.

The acquired data may be divided into two groups: traits connected with the character (related to inborn features) and other traits connected with the upbringing and socialisation. On analysing the findings of the author's research, one should conclude that diligence, courage, precision, commitment and expertise were regarded by the successors as the most useful traits of character. As to the traits regarded as very useful, the surveyed underlined, in most cases, those traits that can be acquired through upbringing and socialisation. The surveyed highlighted that the expertise they acquired while working for a family company, opportunities to make independent decisions affect their commitment to work. They claim that the said commitment is a proof of diligence, whereas the latter proves one's precision. The respondents linked the courage with the upbringing in a family. Parents shape, during the upbringing process, their children's courage to take decisions and their attitude to self-determination. And that is inextricably connected with courage (13-17\% of the surveyed selected these features as the most useful ones).

Three traits were selected as the least used in the succession process: ambition, intelligence and innovativeness. They are connected with inborn personalityrelated qualities of people (merely $4 \%$ of the surveyed regarded them as the most useful in the succession process). Presented percentage data related to the most 
useful traits mean that in the successors' opinion the traits and competencies acquired during the upbringing in the family business are more useful in the development of entrepreneurial competencies, improving, at the same time, their succession potential as to personal traits.

The profile of successors' competences, elaborated byWięcek-Janka i Hadryś-Nowak (2016), contains a set of competencies needed in the succession process conducted in the family firms. Diligence was selected as the most useful competence. Being interpreted as perseverance and determination to execute one's own tasks, diligence is particularly important during succession. Without the said competence, the successors could be subject to pressures from their parents, on the one hand, and pressures from the employees, on the other hand. Thus, they could not be able to deal with tensions and frequent conflicts. Successors highlighted that without the so-defined diligence, it would be difficult for them to overcome conflicts and crises that would appear in the course of succession. The second highly valued competence was expertise, being a proof that it is necessary to involve potential successors in practical aspects of their future profession. Sector-related expertise is connected, through the development of the professional skills, to the professional experience. Thus, a great impact of educating children in business culture was confirmed. Furthermore, the successors highly valued the significance of ethical behaviours in the succession process, which may be connected with the necessity to carry out the succession process in a transparent way, along with an attitude that favours solution-finding process, as a way to protect interests of parties involved in the succession. Courage and creativity are also viewed as needed in the succession process (both competences are marked in the quoted studies as of key importance). The remaining competencies under the survey were given average marks (Więcek-Janka and Hadryś-Nowak, 2016).

Upon the analysis of the studies by the researchers cited herein, and of the results of the author's own research related to successors competencies being a determinant for effective management of modern family firms, the author put an emphasis on three groups of competencies, as provided for in the Figure 1.

It should be underlined that the management of a family firm requires - apart from having traditional competencies to manage such companies - to focus on the role of competencies, resulting from the companies' specific character, with a special emphasis given to emotional intelligence. Differences between family firms and non-family firms evolve mainly around values, organisational culture and aim hierarchy. The said type of enterprises features a specific identity, as well as values and problems related to the conducted activity.

Managing a family business is more difficult than a non-family business and than "managing" a family which is not connected to the business. It transpired that the level of difficulty in managing a family business is not a simple aggregate of levels of difficulty in managing a company and a family; it is something 
Figure 1. Profiles of competencies of successors in modern family companies

Source: Own work.

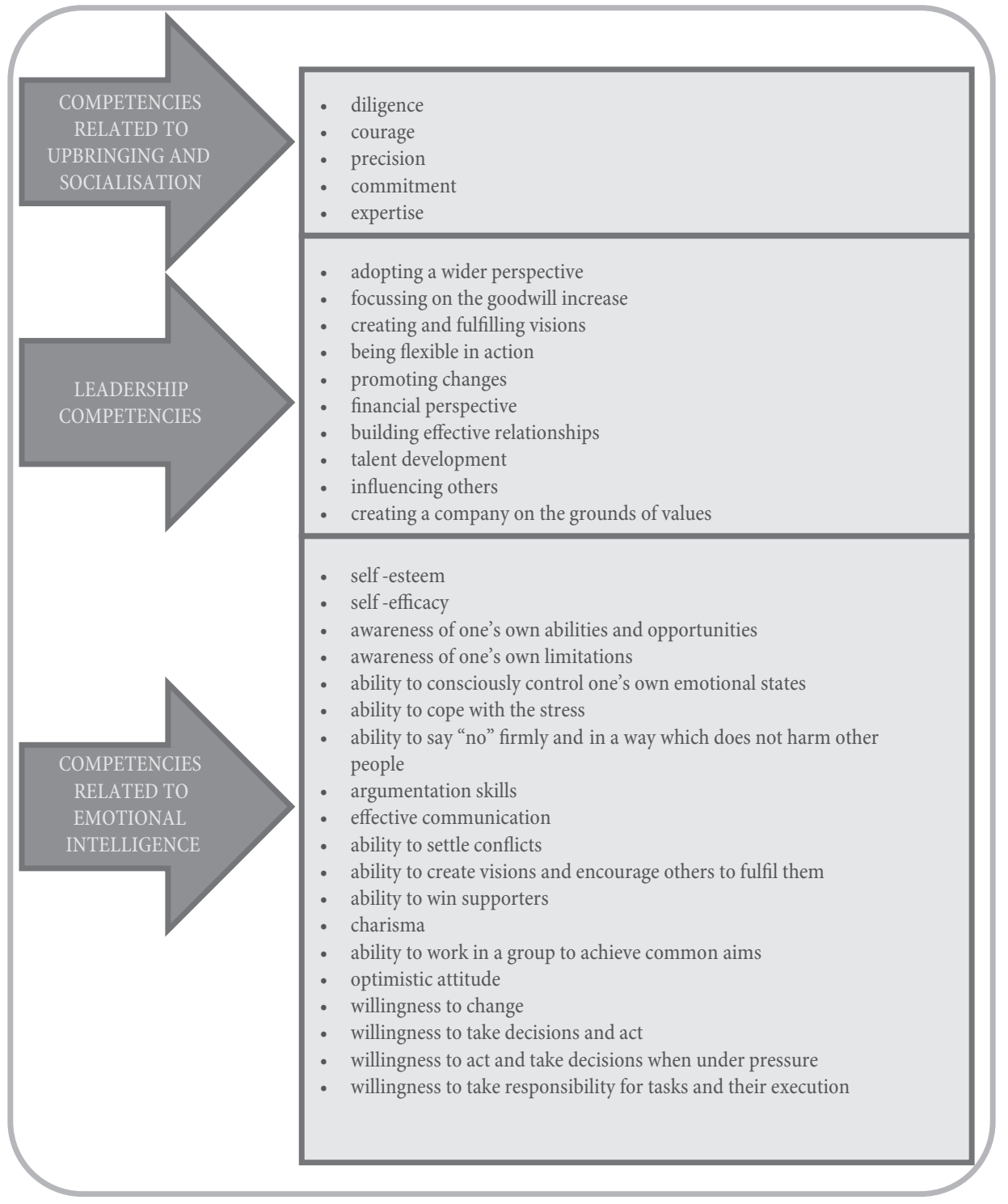


considerably greater, as any failure in the company immediately affects the family, while any family crisis has an effect on the company (Blikle, 2012).

Apart from market rights, aspects of a typically economic and financial character, apart from strategic aspects of the management, there appear streams of non-tangible resources of a specific character. Within the entities, a specific role is played by family bonds, attachment to family values and determination to prolong the entrepreneurial "dynasty" (Tomski, 2011). This, among others, brings about that the challenges the family business successors have to face are constantly growing, which, in turn requires from the successors to possess specific competencies.

\section{Summary}

As the market economy relies, to a considerable extent, on family firms, the succession problem has become common and pressing (Bracci and Vagnoni, 2011). The experience shows that $50 \%$ of family firms will be able to deal with succession-related problems, whereas as few as $15 \%$ of companies will manage to hand the company over to the third generation (Sułkowski and Marjański, 2009).

The unique character of family companies may transpire from their prevalence, the latter resulting from a long-term vision, an ability to take prompt decisions and ability to behave in accordance with trust, loyalty and personal relationships.

Effective addressing of challenges of contemporary companies requires significantly more than just proficient management of tasks. It requires greater interpersonal skills, committed people and a transparent system of values. In such conditions one may experience a growing need to find more appropriate predicators of professional successes and life achievements than mere traditional skills.

Having a wide range of leadership competencies by family business successors determines the ability to effectively recognise market opportunities and achieve business targets. The upbringing in the atmosphere of a family business, the knowledge of its specific character, a new view on it, the willingness to change the status quo, courage and determination of young successors, all that may be a source of opportunities for a family firm to develop.

More and more family businesses have been facing a decision to launch a succession process, which is mainly connected with the handing over of responsibility and management. And to this end the future managers of the said companies are required to possess determined competencies. One should bear in mind that the specific character of the family business management entails a necessity to take into consideration not only economic aspects, but also interpersonal relations in their broad sense. Thus, it is necessary for the successors to possess not only textbook competencies; one should also have intuition, imagination, courage and determination. 
COMPETENCIES PROFILES OF SUCCESSORS

Mariola Dźwigoł-Barosz

\section{Notes}

[1] Corporate Social Responsibility - (CSR). A concept, according to which companies, when elaborating their strategies, deliberately take into consideration social issues and environment protection, as well as relationships with various groups of stakeholders.

[2] Findings of the report entitled „Polish managers in the time of crisis” are a continuation of a study conducted under the programme Talent Club - Polski Menedżer 2009. The study was carried out by means of online questionnaires to be found at www.talentclub.pl, from March to September 2009. 285 respondents took part in the survey. The study „Polski Menedżer 2009” covered 1,461 managers, participants in the Talent Club programme. The study was held from 19.09.2008 to 30.09.2009.

[3] „Wyścig szczurów to przeżytek”, www.rp.pl/artykul/551452.html.

[4] Report from the study: Key success factors. Competencies of the future in family businesses 2017, https://ec.europa.eu/epale/sites/epale/files/raport_kompetencje_firm_rodzinnych.pdf, kwiecień 2017, p. 15.

[5] The study was carried out in the Silesian Voivodeship from September 2016 to February 2017. The questionnaire was completed by 27 successors who manage family firms, at least as a second generation.

\section{References}

Blikle, A. (2012), „Specyfika zarządzania w firmach rodzinnych”, in: Firma w rodzinie czy rodzina w firmie. Metodologia wsparcia firm rodzinnych, PARP, Warszawa.

Bracci, E., Vagnoni, E. (2011), "Understanding Small Family Business Succession in Knowledge Management Perspective, The IUP - Journal of Knowledge Management, Vol. IX No. 1.

Gardner, H. (1989), Frames of Mind. Theory of Multiple Intelligences, Basic Books, New York.

Goleman, D. (1996), Emotional Intelligence: Why It Can Matter More Than IQ, Bantam Books, New York.

Gudkova, S. (2014), „Gen przedsiębiorczości rodzinnej”, Relacje - magazyn firm rodzinnych, Vol. 6 No. 7, pp. 4-5.

Mikołajewska, E., Mikołajewski, D. (2013), „Informatyka afektywna w zastosowaniach cywilnych i wojskowych", Zeszyty Naukowe WSOWL we Wrocławiu, No. 2.

Fundacja Firmy Rodzinne (2017), „Kluczowe składniki sukcesu. Kompetencje przyszłości w firmach rodzinnych", available at: https://ec.europa.eu/epale/sites/epale/files/ raport_kompetencje_firm_rodzinnych.pdf (accessed 15 April 2017).

Smoliński, M., Zakrzewska, L. (2017), „Przywódca musi być zaangażowany”, Harvard Business Review, Special Issue.

Sułkowski, Ł., Mariański, A. (2009), Firmy rodzinne, jak osiągnąć sukces w sztafecie pokoleń, Poltext, Warszawa.

Thor, W., Georgijew, I. (2014), „Biznes potrzebuje lidera o nowym typie kompetencji”, Harvard Business Review Polska, No. 9.

Tomski, P. (2011), „Programowanie przyszłości biznesu w oparciu o więzi rodzinne wybrane problemy sukcesji”, Przedsiębiorczość i Zarządzanie, Vol. 12 No. 7.

Weroniczak, L. (2012), „Dialog międzypokoleniowy”, in: Firma w rodzinie czy rodzina $w$ firmie. Metodologia wsparcia firm rodzinnych, PARP, Warszawa. 
Więcek-Janka E. (2014), „Kompetencje menedżerskie sukcesorów - inżynierów w firmach rodzinnych", Przedsiębiorczość i Zarządzanie, Vol. 15 No. 8.

Więcek-Janka, E., Hadryś-Nowak, A. (2016), „Kompetencje sukcesorskie - profil SUCCESSORS wstępny”, Przedsiębiorczość i Zarządzanie, SAN, Łódź-Warszawa, Vol. 17 No. 6.

Mariola Dźwigoł-Barosz „Wyścig szczurów to przeżytek”, available at: www.rp.pl/artykul/551452.html. 